\title{
Martin Greschat, Der Protestantismus in der Bundesrepublik Deutschland (1945-2005), Evangelische Verlagsanstalt, Leipzig 2010, ss. 245 (Kirchengeschichte in Einzeldarstellungen, IV/2)
}

$\mathrm{N}$ owa książka Martina Greschata (ur. 1934), emerytowanego profesora Justus-Liebig-Universität w Giessen, nie jest obszernym, faktograficznym podręcznikiem, gdyż - jak podkreśla autor - Internet zasypuje nas lawiną informacji, z którą tradycyjne publikacje nie są w stanie konkurować. Zadaniem historyka jest w tej sytuacji selekcja informacji oraz umieszczenie ich we właściwym kontekście tak, by zwłaszcza młodszym czytelnikom umożliwić orientację w skomplikowanej przeszłości, a tym z nich, którzy są ewangelickimi chrześcijanami, także pomóc w konstruowaniu własnej tożsamości. W ten sposób powstało dzieło zwięzłe, ale będące efektem wieloletniego doświadczenia, a przede wszystkim umiejętnego łączenia pracy naukowej i dydaktycznej. Książa nie ma wprawdzie tradycyjnego wstępu omawiającego stan badań, źródła i metody badawcze, ale jest zaopatrzona w obszerną bibliografię i przypisy, które często odwołują się do materiałów archiwalnych. Na uwagę zasługuje także sam tytuł pracy, wskazujący, że przedmiotem rozważań nie są Kościoły ewangelickie, ale protestantyzm, którego dzieje rozumiane są - by odwołać się do sformułowania Kurta Nowaka - jako coś więcej i zarazem mniej niż tradycyjnie pojmowana historia Kościoła. Coś więcej, gdyż autor szeroko przedstawia warunki polityczne, społeczne i kulturalne, w jakich funkcjonowały Kościoły ewangelickie, wywierając wpływ na otaczające je środowisko - ale też coś mniej, gdyż wewnętrzne dzieje Kościołów interesujące są tylko w takim zakresie, jaki jest potrzebny, by wyjaśnić pozakościelny wpływ protestantyzmu*. Prezentowana książka jest zatem opracowaniem interdyscyplinarnym, łączącym dorobek historii Kościoła, historii religii i historii powszechnej w jedną całość. Niewątpliwym atutem autora było jego przygotowanie teologiczne - Martin Greschat jest ordynowanym duchownym, a w Giessen był profesorem Wydziału Teologii Ewangelickiej, dzięki czemu nie tylko lepiej niż historycy świeccy zna mechanizmy funkcjonowania instytucji kościelnych, ale także uwzględnia w swoich rozważaniach debaty i spory teologiczne, praktycznie pomijane przez historyków specjalizujących się w dziejach politycznych czy społecznych.

Książka składa się z pięciu rozdziałów, których podział i tytuły nawiązują do historii politycznej. Pierwszy rozdział, zatytułowany „Lata powojenne” (Die

* K. Nowak, Geschichte des Christentums in Deutschland. Religion, Politik und Gesellschaft vom Ende der Aufklärung bis zur Mitte des 20. Jahrhunderts, München 1995, s. 9. 
Nachkriegszeit) charakteryzuje problemy odbudowy struktur kościelnych i utworzenia Kościoła ewangelickiego w Niemczech (EKD), skupiającego protestantów we wszystkich czterech strefach okupacyjnych. Szczególną uwagę poświęcił autor kwestii uporania się z oceną własnych postaw w okresie Trzeciej Rzeszy, wskazując przy tym, że przyjęta w 1945 r. w Stuttgarcie deklaracja winy powstała w nadziei na wznowienie kontaktów ekumenicznych z obiecującymi pomoc współwyznawcami w Europie Zachodniej. Środowiska kościelne zostały w niewielkim stopniu dotknięte procesem denazyfikacji, co sprawiło, że w środowiskach ewangelickich przetrwała tradycyjna, konserwatywna mentalność, ostro reagująca na wszelkie - także wewnątrzkościelne - głosy krytykujące rolę protestantyzmu w najnowszych dziejach Niemiec.

Radykalnym przemianom mentalności nie sprzyjała atmosfera lat 50., którą Greschat charakteryzuje w rozdziale drugim, zatytułowanym „Era Adenauera” („Die Ära Adenauer”). Liberalne kręgi protestanckich duchownych i świeckich działaczy (w tym tak znane osobistości jak Martin Niemöller czy Gustav Heinemann) krytycznie oceniały politykę kanclerza Adenauera, wskazując, że integracja RFN z Europą Zachodnią oraz zwłaszcza remilitaryzacja republiki bońskiej oznaczać będą pogłębienie podziału Niemiec. Co więcej, Adenauera jako katolika oskarżano o celowe odwrócenie się od przeważająco ewangelickich rodaków w NRD, co miało służyć umocnieniu katolicyzmu w RFN. Krytycy nie uzyskali jednak wsparcia ze strony EKD, a wynik wyborów w 1953 r. (45,2\% dla CDU/ CSU) pokazał, że ich poglądy nie znalazły szerokiego oddźwięku w społeczeństwie. W efekcie RFN utworzyła siły zbrojne i przystąpiła w 1955 r. do NATO, a władze kościelne wsparły te działania, godząc się na utworzenie duszpasterstwa wojskowego, nie bacząc na następstwa w postaci rozłamu EKD na część zachodnioi wschodnioniemiecką.

Trzeci rozdział „Dekada przełomów” („Ein Jahrzehnt der Umbrüche”) poświęcony jest okresowi lat 60 . Zapoczątkowany on został odezwą opublikowaną na łamach tygodnika „Die Zeit”, zawierającą wezwanie grupy protestanckich intelektualistów do rewizji polityki Adenauera, w tym uznania granicy na Odrze i $\mathrm{Ny}$ sie Łużyckiej. Jak podkreśla Martin Greschat, w przestrzeni publicznej pojawiło się w ten sposób zupełnie nowe oblicze protestantyzmu, akcentujące swoje liberalnodemokratyczne przekonania mocno zakorzenione w wartościach Zachodu, i tym samym mocno różniące się tak od hierarchii kościelnej, jak i od czołowych działaczy partyjnych. To w dużym stopniu dzięki tej grupie udało się ostatecznie przeforsować ogłoszony w 1965 r. słynny memoriał wschodni (Ostdenkschrift) Kościoła ewangelickiego w Niemczech, wskazujący na potrzebę pojednania Niemców ze wschodnimi sąsiadami oraz sugerujący konieczność uznania granicy na Odrze i $\mathrm{Ny}$ sie Łużyckiej. Memoriał ten wywołał wprawdzie burzliwą dyskusję w RFN, ale jed- 
nocześnie utorował drogę do traktatu z Polską, podpisanego przez kanclerza Willy Brandta w Warszawie w 1970 r.

Lata 60. to jednak czas nie tylko przełomów politycznych, ale także społecznych i religijnych. Sobór Watykański II otworzył drogę ku ekumenicznym kontaktom ewangelików z katolikami, a rewolta młodzieży z jej krytyką neokolonializmu przyczyniła się do nawiązania ścisłych kontaktów ekumenicznych z Kościołami protestanckimi krajów Trzeciego Świata, zwłaszcza afrykańskimi. Polityczne zaangażowanie kierownictwa EKD oraz duchownych ewangelickich budziło jednak sprzeciw części konserwatywnych środowisk protestanckich, które zainicjowały ruch o charakterze fundamentalistycznym, kładący nacisk na pielęgnowanie pobożności i sprzeciwiający się naukowej egzegezie Ewangelii, prowadzonej przez uniwersyteckich wykładowców teologii, pozostających pod wpływem Rudolfa Bultmanna i jego koncepcji demitologizacji Biblii.

Tematem czwartego rozdziału, zatytułowanego „Niespokojne uspokojenia” („Unruhige Beruhigungen”), są lata 70., które według autora charakteryzowały się napięciami i kryzysami, skutecznie przezwyciężanymi przez kanclerza Helmuta Schmidta. Ta burzliwa dekada przyniosła dalszą transformację i jednocześnie polaryzację zachodnioniemieckiego protestantyzmu. Najwięcej uwagi poświęcił autor radykalizacji środowisk liberalnych, które wyraźnie zbliżyły się do socjalizmu, a ich upolitycznienie osiągnęło swoiste apogeum podczas sporu o prawo przynależności duchownych do Niemieckiej Partii Komunistycznej (DKP) w 1973 r. oraz gestów zrozumienia dla ideałów, którymi kierowali się terroryści RAF w drugiej połowie dekady. Angażowanie się protestanckich środowisk w liczne nowe ruchy społeczne, w tym zwłaszcza ekologiczne i pokojowe, przyniosło jednak tym mocniejszy sprzeciw nurtu konserwatywno-fundamentalistycznego. Co więcej, brak jednolitego głosu Kościoła w zasadniczych kwestiach społecznych i politycznych przyczynił się do dystansowania się coraz szerszych kręgów społeczeństwa od tradycyjnego, instytucjonalnego życia parafii.

Kryzysowe tendencje i nastroje bynajmniej nie zostały przezwyciężone po 1990 r., na co wskazuje Greschat w ostatnim rozdziale, zatytułowanym „W zjednoczonych Niemczech” („Im vereinten Deutschland”). Upadek NRD i przyłączenie tamtejszych Kościołów krajowych do EKD umocniło tylko zachodnioniemieckich ewangelików w przekonaniu o słuszności dotychczasowych postaw i działań. Próba rozciągnięcia zachodniego modelu funkcjonowania Kościoła na całe Niemcy spotkała się jednak z oporem w nowych landach, którego nie osłabiło nawet ujawnienie licznych przypadków współpracy świeckich i duchownych ewangelików w NRD ze służbą bezpieczeństwa Stasi. Zlaicyzowane społeczeństwo wschodnich Niemiec wykazywało zresztą niewielki, nieprzekraczający $25 \%$ odsetek osób należących do Kościołów ewangelickich, a wprowadzenie nauczania religii w szkołach, duszpaster-

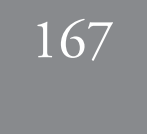


stwa wojskowego, czy zaostrzenie ustawy antyaborcyjnej wywołało gorące debaty. Niemiecki protestantyzm wkroczył zatem w XXI stulecie w atmosferze narastającego kryzysu, którego widomych znakiem jest spadająca liczba wiernych oraz malejąca liczba parafii. Jak podkreśla Martin Greschat, do jego przezwyciężenia konieczna jest refleksja nad okresem po 1945 r., który przyniósł fundamentalną zmianę mentalności i wypracował model „Kościoła wolności”. Jego dalsze funkcjonowanie nie może opierać się wyłącznie na zasadach przedsiębiorstwa kierującego się rachunkiem zysków i strat, ale powinno zwrócić się ku głoszeniu Ewangelii i pogłębianiu duszpasterstwa, co w dalszej perspektywie umocni także społeczne i kulturowe czynniki poprawiające efektywność funkcjonowania gospodarki.

Książka Martina Greschata to dzieło historyka będącego także zaangażowanym uczestnikiem wielu opisywanych wydarzeń. Liczne, ale krótkie cytaty i niejednokrotnie emocjonalny styl narracji nie pozwalają jednak na stwierdzenie, by była to książka tendencyjna - przeciwnie, autor bardziej stara się wyjaśniać niż oceniać charakteryzowane postaci i wydarzenia. Osoby znające Greschata jako przewodniczącego Komisji Historycznej Polskiej Rady Ekumenicznej i Kościoła Ewangelickiego w Niemczech mogą być zawiedzione, że niewiele miejsca zajmują w jego książce sprawy polskie (poza kwestią granicy na Odrze i Nysie Łużyckiej), ale być może właśnie to jest potwierdzeniem naukowej rzetelności autora, który w syntetycznym opracowaniu potrafił ukazać zróżnicowaną problematykę we właściwych proporcjach.

Olgierd Kiec (Zielona Góra)

Markus Krzoska (Hg.), Erinnerungen des Posener Domherren Albert Steuer, Martin Meidenbauer Verlagsbuchhandlung, München 2010, ss. 246 (Polono-Germanica 5, Schriften der Kommission für die Geschichte der Deutschen in Polen e.V.)

$\mathrm{P}$ olsko-niemiecki antagonizm narodowy w XIX i XX wieku posiadał swój wymiar religijny, który w potocznej świadomości historycznej funkcjonuje jako konflikt „polskiego katolicyzmu” z „pruskim protestantyzmem”. Tymczasem niemały odsetek katolików w Wielkopolsce stanowili Niemcy, którzy zresztą cieszą się dużo większym zainteresowaniem polskiej historiografii niż niemieccy i polscy 